\title{
Validasi Alat Ukur Digital Literacy pada Individu Dewasa Awal
}

\author{
FITHRA AULIAWAN \& RAHKMAN ARDI*
}

Departemen Psikologi Kepribadian dan Sosial, Fakultas Psikologi Universitas Airlangga

\begin{abstract}
ABSTRAK
Penelitian ini bertujuan untuk menguji menguji validitas skala digital literacy yang dikembangkan Wan $\mathrm{Ng}$ pada individu dewasa awal. Digital literacy merupakan suatu kemampuan yang dibutuhkan individu untuk beraktivitas pada dunia digital secara optimal, khususnya pada individu dewasa awal. Metode penelitian yang digunakan adalah menggunakan metode survei dengan memberikan kuesioner online pada partisipan yang telah ditentukan kriterianya. Hasil analisis menunjukan bahwa terdapat validitas pada skala digital literacy yang dikembangkan Wan Ng pada individu dewasa awal. Berdasarkan analisis kriteria eigenvalues terdapat 3 faktor yang dihasilkan dengan rentang nilai factor loading 0.49 dan -0.88 , serta terdapat 1 item yang perlu dieliminasi. Berdasarkan analisis kriteria fixed number terdapat 1 faktor yang dihasilkan dengan rentang nilai factor loading 0.48-0.78 dan item yang dieliminasi berjumlah 3. Meskipun item digital literacy sudah memenuhi kriteria validitas, Studi lanjut diperlukan untuk menyempurnakan alat ukur digital literacy.
\end{abstract}

Kata kunci: alat ukur, digital literacy, individu dewasa awal, validasi

\begin{abstract}
This study aims to test the validity of the digital literacy scale developed by Wan $\mathrm{Ng}$ in early adult individuals. Digital literacy is an ability that individuals need to do activities in the digital world optimally, especially in early adulthood individuals. survey method used by providing an online questionnaire to the participants whose criteria have been determined. The analysis shows that there is validity on the digital literacy scale developed by Wan $\mathrm{Ng}$ in early adult individuals. On the analysis of the criteria for eigenvalues, there are 3 factors generated with a loading factor value range of 0.49 and 0.88 , and there is 1 item that eliminated. On the analysis of the number criteria, there is 1 factor generated with a loading factor value range of 0.48-0.78 and the eliminated item is 3 . Even though the item meets the validity criteria, further studies are needed to improve digital literacy scale.
\end{abstract}

Keywords: digital literacy, early adulthood individual, measurment tool, validation

Buletin Penelitian Psikologi dan Kesehatan Mental (BRPKM), 2021, Vol. 1(1), 229-241

*Alamat korespondensi: Fakultas Psikologi Universitas Airlangga, Kampus B Universitas Airlangga Jalan

Airlangga 4-6 Surabaya 60286. Surel: rahkman.ardi@psikologi.unair.ac.id

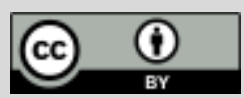

Naskah ini merupakan naskah dengan akses terbuka dibawah ketentuan the Creative Common Attribution License (CC-BY-4.0) (http://creativecommons.org/licenses/by/4.0), sehingga penggunaan, distribusi, reproduksi dalam media apapun atas artikel ini tidak dibatasi, selama sumber aslinya disitir dengan baik. 


\section{PEN D A H U L U A N}

Perkembangan teknologi digital telah memberikan dampak perubahan pada aspek kognitif, perilaku, dan afektif dalam aktivitas manusia yang berbeda dibanding pada dimensi tatap muka (Suler, 2004). Perubahan dalam aspek kognitif terjadi pada faktor atensi dan kecepatan proses berpikir (Tapscott, 2009). Menurut riset yang dilakukan Oxford Future of the Mind Institute (2007) terkait generasi internet, diketahui generasi internet yang terpapar teknologi digital memiliki kecepatan berpikir yang lebih baik dibandingkan generasi sebelumnya, namun lebih sulit pulih kembali dari distraksi saat melakukan aktivitas kognitif yang kompleks (Bawden D. ,2008). Pada aspek afektif perubahan terjadi dalam pengekspresian emosi individu yang dipengaruhi self-disclosure pada dunia digital (Barak, 2008). Keberadaan Self-disclosure yang tinggi saat berkomunikasi menggunakan teknologi digital menyebabkan individu lebih terbuka dan bebas dalam mengekspresikan emosi dibandingkan pada komunikasi pada dimensi tatap muka (Barak, 2008). Perubahan perilaku yang muncul akibat perkembangan teknologi digital adalah perilaku multitasking (Circella, dkk., 2012). Perilaku multitasking memungkinkan individu untuk melakukan berbagai aktivitas dalam satu waktu secara bersamaan (Circella, dkk., 2012). Kemudahan Individu dalam melakukan berbagai macam aktivitas secara bersamaan terjadi karena teknologi digital yang menjadi fasilitator penunjang aktivitas-aktivitas tersebut (Brasel \& Gips, 2011).

Selain memberikan dampak positif, perubahan tersebut juga dapat memberikan dampak negatif pada pengguna. Dampak negatif tersebut merupakan risiko yang muncul akibat dari konsekuensi penggunaan teknologi digital (Rice, dkk., 2016). Risiko penggunaan teknologi digital tersebut berupa perilaku-perilaku menyimpang seperti cyberbullying, cyberracism, ujaran kebencian, cybercrime, adiksi internet, blackmailing dan pelecehan seksual (Wu, Lee, Shih-Cheng, \& Chang, 2015). Risiko penggunaan teknologi digital lainnya adalah individu menjadi lebih mudah terdistraksi dan mengalami kesulitan dalam memusatkan atensi (Tapscott, 2009). Generasi milenial yang merupakan individu dengan usia 20-24 menjadi kelompok pengguna teknologi internet terbanyak di Indonesia, yaitu sebanyak 88,5\% (Haryanto, 2019). Dampaknya pengguna teknologi internet pada masa dewasa awal menjadi kelompok yang rentan terhadap risiko penggunaan teknologi digital. Selain menjadi kelompok yang paling rentan terhadap risiko penggunaan teknologi digital di Indonesia, individu dewasa awal juga merupakan fase di mana individu mengalami keterlibatan yang signifikan dalam berwarganegara (Kahne, Lee, \& Feezell, 2013). Hal tersebut membuat mereka perlu menyiapkan diri dengan konsep berwarga negara dalam lingkungan digital (Choi, Glassman, \& Cristol, 2017). Individu dewasa awal juga memiliki urgensi dalam bidang pekerjaan (Hutteman, dkk., 2014). Urgensi ini muncul karena pada masa dewasa awal individu mengalami transisi peran dari fase perkembangan sebelumnya, di mana individu memiliki peran baru dalam bidang pekerjaan dan keluarga (Lechner, Sortheix, Gollner, \& Katarina, 2017). Teknologi digital yang telah menjadi aspek penting dalam mengefektifkan pekerjaan pada lingkungan kerja membuat individu dewasa awal perlu memiliki kompetensi dalam penggunaan teknologi (Zhang, et al., 2013).

Keberadaan digital literacy dibutuhkan sebagai kemampuan untuk bertahan di lingkungan digital dan menjadi alat dalam mencegah risiko akibat dampak penggunaan teknologi (Rodríguez, Igartua, \& González-Vázquez, 2016). Menurut Eshet (2004) digital literacy bukan hanya sekedar kemampuan dalam menggunakan komputer dan mengakses internet, namun kemampuan kognitif individu menggunakan teknologi digital secara tepat dalam pengelolaan informasi dan berperilaku secara etis pada lingkungan digital. Menurut Ng (2012) digital literacy adalah beragam literasi yang diasosiasikan dalam penggunaan teknologi digital. Saat ini digital literacy juga menjadi sebuah kemampuan yang esensial pada berbagai bidang pekerjaan, sehingga kompetensi dalam penggunaan teknologi digital menjadi sesuatu yang wajib dimiliki dalam masyarakat (Osterman, 2012). Kim, dkk., (dalam Noh, 2017) menyatakan bahwa individu yang memiliki level digital literacy yang tinggi dapat berfungsi secara efektif dalam berkomunikasi dan bekerja di lingkungan digital. Selain itu digital literacy juga menjadi 
faktor prediktor pada perilaku privasi dalam lingkungan digital (Park, 2011). Selain itu menurut Park (2011) keberadaan digital literacy mempengaruhi individu dalam berperilaku dan beraktivitas pada dunia maya.

Meskipun demikian banyak pengguna teknologi digital di Indonesia masih tidak memahami dan menyadari terkait pentingnya digital literacy. Hal ini dibuktikan dengan ditemukannya perilakuperilaku pada pengguna teknologi yang mengindikasikan tidak berliterasi digital seperti kejahatan siber, cyberbullying, dan penyebaran hoaks (Kurnia \& Astuti, 2017). Hal tersebut didukung dengan temuan 3.429 kasus Kejahatan Siber dalam periode Januari sampai Agustus 2019 (CNN Indonesia, 2019). Selain itu juga ditemukan sebagian sumber daya manusia di Indonesia yang tidak memiliki kompetensi dalam Teknologi Informasi Komunikasi (TIK), sehingga memberikan permasalahan pada bidang ketenagakerjaan (Iskandar, 2017). Seharusnya pengguna teknologi digital di Indonesia perlu memahami aspek-aspek digital literacy seperti aspek sosial-emosional, aspek teknis, dan aspek kognitif secara komprehensif dan holistik dalam mencegah risiko dan mengoptimalkan penggunaan teknologi pada lingkungan digital $(\mathrm{Ng}, 2012)$. Berdasarkan deskripsi tentang realitas perilaku negatif di lingkungan digital pada sebagian orang Indonesia, maka dapat disimpulkan bahwa terdapat fenomena defisiensi literasi digital (Park, 2011).

Dalam upaya menindaklanjuti tantangan dan permasalahan yang berkaitan dengan digital literacy pada pengguna teknologi digital pada individu dewasa awal, dibutuhkan alat ukur yang dapat dipakai untuk melihat sejauh mana literasi digital yang dimiliki oleh orang Indonesia dalam beraktivitas di lingkungan digital secara empiris dan terstandar. Alat ukur yang terstandar adalah alat ukur yang memenuhi syarat validitas dan reliabilitas (Sprinthall, Schmutte, \& Sirois, 1991). Keberadaan alat ukur digital literacy sangat penting sebagai asesmen awal kemampuan literasi digital individu yang berguna sebagai dasar dalam pengambilan keputusan (Osterman, 2012). Keberadaan alat ukur digital literacy di Indonesia sangat dibutuhkan dalam membantu pemecahan masalah yang terkait dengan konsep literasi digital. Berdasarkan penelitian sebelumnya pengembangan dan validasi alat ukur digital literacy di luar negeri telah banyak dilakukan (Üstündağ, Güneş, \& Bahçivan, 2017)

Berdasarkan pemaparan dan urgensi yang telah diuraikan di atas, maka peneliti memutuskan untuk melakukan penelitian terkait validasi alat ukur digital literacy pada individu dewasa awal menggunakan konsep digital literacy Ng (2012). Tujuan penelitian ini adalah menguji validitas skala digital literacy yang dikembangkan oleh Ng (2012) pada individu dewasa awal. Peneliti memilih konsep digital literacy Ng (2012) dikarenakan konsep tersebut memiliki kesesuaian dengan karakteristik target pengembangan alat ukur, yaitu individu pada masa dewasa. Selain itu pada penelitian sebelumnya konsep digital literacy $\mathrm{Ng}$ (2012) juga telah digunakan pada konteks dewasa awal dalam pengembangan alat ukur. Pada penelitian ini peneliti ingin menguji hipotesis apakah skala digital literacy yang dikembangkan Ng (2012) pada penelitian ini memiliki validasi yang baik pada populasi individu dewasa awal.

\section{Digital Literacy}

Konsep digital literacy muncul sebagai kemampuan untuk bertahan di lingkungan digital dan menjadi alat dalam mencegah risiko akibat dampak penggunaan teknologi (Rodríguez, Igartua, \& GonzálezVázquez, 2016). Saat ini digital literacy juga menjadi sebuah kemampuan yang esensial pada berbagai bidang pekerjaan, sehingga kompetensi dalam penggunaan teknologi digital menjadi sesuatu yang wajib dimiliki dalam masyarakat (Osterman, 2012). Pada penelitian ini teknologi digital yang menjadi fokus penelitian adalah teknologi internet serta perangkat pintar; seperti laptop, komputer, dan gadget. Hal ini didasari oleh perkembangan perkembangan perangkat pintar yang meluas, dimana semula hanya muncul pada lingkungan industri dan bidang vital tertentu, sekarang juga terjadi pada lingkungan yang lebih umum seperti di kantor dan rumah (Zhang, et al., 2013). 
Menurut Eshet (2004) digital literacy bukan hanya sekedar kemampuan individu dalam menggunakan komputer dan mengakses internet, namun juga kemampuan kognitif individu menggunakan teknologi digital secara tepat dalam pengelolaan informasi dan berperilaku secara etis pada lingkungan digital. Konsep digital literacy Eshet (2004) menjelaskan bahwa individu perlu memperhatikan aspek kognitif, motorik, sosial, dan emosional dalam menggunakan teknologi pada lingkungan digital. selain itu menurut Menurut Ng (2012) digital literacy adalah beragam literasi yang diasosiasikan dalam penggunaan teknologi digital. Secara spesifik terdapat 3 dimensi pada kerangka konseptual Ng (2012) yang saling berhubungan, yaitu dimensi teknik, dimensi kognitif, dan dimensi sosio-emosional. Selain 3 dimensi diskrit di atas, terdapat juga kemampuan dalam kerangka konseptual digital literacy yang muncul dari interseksi antar dimensi. Faktor-faktor yang mempengaruhi digital literacy adalah perbedaan generasi dan digital divide (Prensky, 2001; Deursen \& Dijk, 2010).

\section{Dewasa Awal}

Menurut teori psikososial Erikson (1968) terdapat delapan tahap perkembangan yang dialami manusia sepanjang hidup mereka (Haber, 2006). Teori psikososial Erikson memberikan perspektif yang luas terkait mekanisme individu dalam menghadapi tantangan yang muncul pada setiap fase perkembangan (Svetina, 2014). Pada setiap fase perkembangan terdapat konflik internal dan krisis yang menjadi tantangan perkembangan dan merupakan representasi dari periode kritis di setiap masa perkembangan (Haber, 2006). Individu perlu menyelesaikan tantangan perkembangan tersebut agar dapat berpindah pada fase perkembangan selanjutnya (Svetina, 2014). Fase dewasa awal terjadi sebelum fase dewasa tengah dan sesudah fase remaja. Menurut Havighurst (1972) fase dewasa awal terjadi pada umur 18-30 tahun (Hutteman, dkk., 2014). Pada fase dewasa awal terdapat terdapat krisis internal berupa tantangan perkembangan yang perlu dihadapi, yaitu intimacy versus isolation (Kroger, 2015). Dalam tantangan perkembangan ini individu mulai memutuskan untuk membangun hubungan dengan dengan orang lain yang dapat termanifestasi dalam berbagai bentuk, seperti pertemanan dengan lawan jenis, pasangan, persahabatan dan rekan (Kroger, 2015).

\section{Alat Ukur Digital Literacy}

Berdasarkan penelitian sebelumnya terdapat berbagai macam studi terkait pengembangan alat ukur digital literacy. Rodríguez-de-Dios, dkk (2016) melakukan pengembangan dan validasi alat ukur digital literacy dengan target remaja menggunakan exploratory factor analysis (EFA), dan hasilnya menunjukan terdapat enam faktor yang menjadi dasar digital literacy. Üstündağ, dkk (2017) juga melakukan pengembangan dan validasi alat ukur digital literacy dengan mengadaptasi skala digital literacy yang dikembangkan oleh $\mathrm{Ng}$ (2012). Skala digital literacy yang diadaptasi tersebut dibuat dengan menggunakan aspek pada konsep digital literacy Ng (2012). Alat ukur Üstündağ, dkk (2017) tersebut selanjutnya diujikan pada 979 guru dari 13 universitas negeri di Turki dan data yang didapatkan dianalisis menggunakan exploratory factor analysis (EFA).

Keberadaan alat ukur digital literacy di Indonesia sangat dibutuhkan dalam membantu pemecahan masalah yang terkait dengan konsep literasi digital. Meskipun terdapat beberapa penelitian terkait konsep literasi digital di Indonesia, namun peneliti tidak menemukan penelitian terkait validitas alat ukur digital literacy yang empiris dan terstandar pada populasi atau setting Individu dewasa awal di Indonesia. Hal tersebut berdasarkan literatur review yang dilakukan peneliti pada pengindeks jurnal, yaitu Google Scholar, Scopus, Directory of Open Access Journal (DOAJ), dan Portal Garuda dengan kata kunci "validasi", "literasi digital", "skala literasi digital", "validation", "digital Literacy", dan "digital literacy scale" pada tanggal 15 Mei 2020, tidak ditemukan penelitian tentang validasi alat ukur digital literacy dalam setting individu dewasa awal di Indonesia. Padahal penelitian terkait pengembangan dan validasi alat ukur digital literacy di luar negeri telah banyak dilakukan (Üstündağ, Güneş, \& Bahçivan, 2017). 


\section{Desain Penelitian}

\section{E T O D E}

Metode penelitian yang digunakan dalam penelitian ini adalah metode survei yang bertujuan untuk mendeskripsikan kondisi yang terjadi dan mengidentifikasi standar data yang dapat dibandingkan dengan data yang ada (Cohen \& Manion, 1989). Dalam studi kuantitatif survei ini penelitian dilakukan dengan cara memberikan kuesioner yang berisikan skala digital literacy yang sudah ditranslasi peneliti dari penelitian sebelumnya pada populasi dewasa awal. Data dari responden selanjutnya dianalisis menggunakan teknik analisis exploratory factor analysis dengan tujuan untuk mengeksplorasi faktorfaktor yang ada pada variabel digital literacy dan mengetahui validasi dari skala digital literacy $\mathrm{Ng}$ (2012) yang sudah ditranslasi. Pada penelitian ini analisis exploratory factor analysis dilakukan dengan menggunakan 2 kriteria, yaitu kriteria eigenvalues dan kriteria fixed number.

\section{Partisipan}

Pada penelitian ini metode non-probability sampling dengan teknik purposive sampling digunakan untuk mendapat partisipan penelitian yang ingin diteliti, yaitu Individu dewasa awal pengguna teknologi digital dengan rentang umur 18-30. Sebelum pengambilan data dilakukan peneliti menghitung ukuran sampel yang dibutuhkan dalam penelitian ini dengan menggunakan metode maximum-likelihood. Secara spesifik estimasi minimal sampel ditentukan dengan rule of thumb Jackson (2003), yaitu menggunakan rumus N:q dengan ratio 5:1 (Kline, 2011). Berdasarkan rumus perhitungan sampel maximum-likelihood dengan ratio 5:1 tersebut diketahui sampel minimal yang dibutuhkan dalam penelitian ini adalah sebanyak 150 orang. Jumlah partisipan dalam penelitian ini adalah 170 orang $(\mathrm{N}=170)$ yang telah memenuhi kriteria responden penelitian. Partisipan terdiri dari responden berjenis kelamin perempuan 65,9\% $(\mathrm{N}=112)$ dan responden berjenis kelamin laki-laki 34,1\% $(\mathrm{N}=58)$ dengan rentan usia 18-26 tahun $(\mathrm{M}=21,12 ; \mathrm{SD}=1,23)$. Terkait aspek pendidikan, responden yang berpartisipasi pada penelitian ini terdiri dari sarjana/S1 yaitu sebanyak 81,8\% ( $\mathrm{N}=139)$, pelajar SMA 4,7\% ( $\mathrm{N}=8)$, Magister/S2 1,8\% (N=3), dan status pendidikan lainnya (seperti D1, D3, D4) sebanyak 11,8\% (N=20). Partisipan telah diberikan informed consent sebelum berpartisipasi untuk menjadi responden pada penelitian ini.

\section{Pengukuran}

Pada penelitian ini pengukuran atau pengambilan data dilakukan dengan menggunakan skala digital literacy yang sudah ditranslasi dan divalidasi oleh peneliti dari alat ukur pada penelitian sebelumnya. Pada penelitian ini pendekatan applied approach digunakan dalam translasi skala, yaitu aitem dalam skala diterjemahkan tanpa perlu diubah pada konteks budaya yang baru (Van De Vijver, 2016). Skala yang digunakan adalah skala likert yang ditranslasi dari skala digital literacy milik Ng (2012). Skala ini terdiri memiliki 10 item yang terdiri dari 3 dimensi, yaitu dimensi kognitif, teknik, dan sosio-emosional. Dalam skala likert ini terdapat 4 pilihan jawaban yang disediakan yaitu mulai angka 1(sangat tidak setuju) sampai angka 4 (sangat setuju). Pada penelitian ini data partisipan tidak diskor, namun dianalisis menggunakan teknik analisis exploratory factor analysis untuk diketahui nilai factor loadingnya sebagai kriteria penentuan validitas konstruk. Reliabilitas skala setelah dilakukan uji reliabilitas didapatkan nilai sebesar 0,65 untuk faktor/dimensi kognitif, 0,82 untuk faktor/dimensi teknik, 0,44 untuk faktor/dimensi sosio-emosional, dan 0,83 untuk faktor/dimensi digital literacy skill. Terkait validitas, validitas konten dan konstruk digunakan pada penelitian ini. Validitas konten dilakukan sebelum pengambilan data dan validitas konstruk dilakukan setelah pengambilan data. Validitas konten dilakukan dengan professional review menggunakan Content Validity Index (CVI). Hasil Content Validity Index (CVI) menunjukan bahwa skala digital literacy yang digunakan pada penelitian ini memiliki nilai CVI yang memenuhi kriteria validitas Waltz dkk. (2005), yaitu 0,93 untuk S-CVI dan 0,88 untuk I-CVI. 


\section{Analisis Data}

Pada penelitian ini analisis data dilakukan dengan menggunakan teknik exploratory factor analysis menggunakan aplikasi IBM SPSS statistic 22. Teknik exploratory factor analysis (EFA) digunakan untuk mengeksplorasi faktor-faktor yang mendasari pada variabel digital literacy dan meninjau validasi dari alat ukur yang diujikan (Hair, dkk., 2014). Validasi dari item pada skala yang diujikan ditinjau dari nilai factor loading yang muncul pada analisis exploratory factor analysis (EFA) (Field, 2018).

\section{HAS I L P E N E L I T I A N}

Hasil analisis analisis faktor menggunakan Teknik exploratory factor analysis (EFA) berdasarkan kriteria eigenvalues dan kriteria fixed number pada penelitian ini menunjukan bahwa item pada skala digital literacy memiliki nilai factor loading yang memenuhi kriteria validitas Steven (2002) (tabel 1 dan 2), yaitu diatas 0.4 (Field, 2018). Meskipun demikian terdapat berdasarkan 2 analisis tersebut terdapat item yang dieliminasi karena nilai factor loading item tersebut tidak memenuhi tidak memenuhi kriteria validitas Steven (2002). Pada analisis faktor berdasarkan berdasarkan kriteria eigenvalues item yang perlu dieliminasi adalah item DLI1; sedangkan pada analisis faktor berdasarkan berdasarkan kriteria fixed number terdapat 3 item yang perlu dieliminasi, yaitu item DLI1, DLI3, dan DLI4. Selain itu hasil analisis faktor juga menunjukan faktor/dimensi yang dihasilkan dari analisis tersebut, Pada analisis faktor berdasarkan berdasarkan kriteria eigenvalues diketahui terdapat 3 faktor/dimensi yang dihasilkan, sedangkan pada analisis faktor berdasarkan berdasarkan kriteria fixed number hanya terdapat 1 faktor/dimensi yang dihasilkan.

Tabel 1. Hasil analisis faktor berdasarkan kriteria eigenvalues

\begin{tabular}{cccc}
\hline & \multicolumn{3}{c}{ Factor } \\
\cline { 2 - 4 } & $\mathbf{1}$ & $\mathbf{2}$ & $\mathbf{3}$ \\
\hline DLI7 & .89 & & \\
DLI8 & .67 & & \\
DLI6 & .67 & & \\
DLI9 & .49 & & \\
DLI10 & .48 & & \\
DLI3 & & .80 & \\
DLI4 & & .44 & -.88 \\
DLI5 & & & -.49 \\
DLI2 & & & \\
DLI1 & & & \\
\hline
\end{tabular}


Tabel 2. Hasil analisis faktor berdasarkan kriteria fixed number

\begin{tabular}{cc}
\hline & Factor \\
\hline & $\mathbf{1}$ \\
\hline DLI6 & .78 \\
DLI8 & .76 \\
DLI7 & .71 \\
DLI5 & .65 \\
DLI10 & .64 \\
DLI9 & .51 \\
DLI2 & .48 \\
DLI1 & \\
DLI4 & \\
DLI3 & \\
\hline
\end{tabular}

Setelah melakukan analisis faktor, selajutnya analisis reliabilitas dan analisis deskriptif dilakukan pada faktor-faktor yang sudah dihasilkan pada analisis faktor. Analisis Cronbach alpha dilakukan untuk melihat reliabilitas dari item pada faktor-faktor tersebut. Pada faktor yang dihasil dari analisis faktor berdasarkan kriteria eigenvalues nilai reliabilitas yang didapatkan adalah 0,82 untuk faktor teknik, 0,44 untuk faktor sosio-emosional, dan 0,65 untuk faktor kognitif. Hasil analisis deskriptif menunjukan faktor teknik memiliki nilai $(\mathrm{M}=16.07$; $\mathrm{SD}=2.54)$; faktor sosio-emosional memiliki nilai $(\mathrm{M}=7.12 ; \mathrm{SD}=$ 1.07); dan faktor kognitif memiliki nilai ( $M=5.79$; $S D=1.32)$. Sedangkan Pada faktor yang dihasil dari analisis faktor berdasarkan kriteria fixed number nilai reliabilitas yang dihasilkan adalah 0,83 untuk faktor digital literacy skill dan analisis deskriptif dalam faktor tersebut menunjukan nilai $(M=21,86$; $\mathrm{SD}=3,45)$.

\section{I S K U S I}

Hasil analisis faktor menggunakan teknik exploratory factor analysis (EFA) berdasarkan kriteria eigenvalues dan kriteria fixed number menunjukan bahwa skala digital literacy yang dikembangkan oleh $\mathrm{Ng}$ (2012) pada populasi individu dewasa awal telah memiliki validitas yang cukup baik Karena nilai factor loading yang dihasil pada item dalam skala diatas 0.4. Meskipun demikian terdapat item-item yang perlu dieliminasi karena tidak mempunyai factor loading yang cukup dan memenuhi kriteria steven (2002) (Field, 2018).

Hasil analisis faktor yang dilakukan berdasarkan kriteria eigenvalues memiliki hasil berbeda dengan penelitian sebelum yang dilakukan oleh Üstündağ dkk (2017). Hasil analisis faktor skala digital literacy yang dikembangkan oleh Ng (2012) pada penelitian Üstündağ dkk (2017) menunjukan bahwa terdapat 1 faktor yang dapat dipertahankan berdasarkan nilai eigenvalues. Sedangkan pada penelitian ini terdapat 3 faktor yang dapat dipertahankan. Adanya perbedaan hasil tersebut terjadi karena nilai eigenvalues yang nilainya diatas satu pada penelitian ini berjumlah 3. Menurut Field (2018) eigenvalues memberikan penjelasan terkait varians distribusi data, sehingga dapat diketahui bahwa dalam 
penelitian ini varians distribusi data yang didapatkan nilainya lebih besar dibandingkan penelitian sebelumnya yang dilakukan oleh Üstündağ dkk (2017). Pada penelitian ini varians distribusi data memiliki nilai yang lebih besar karena partisipan yang digunakan memiliki diversitas latarbelakang yang lebih luas yaitu pelajar SMA, S1, dan S2 dibandingkan penelitian sebelumnya yang partisipannya dispesifikan hanya pada pre-service teacher.

Terkait reliabilitas pada faktor yang dihasil berdasarkan kriteria eigenvalues pada penelitian ini; faktor teknik memiliki reliabilitas yang baik yaitu diatas 0.7 , sedangkan faktor sosio-emosional dan kognitif tidak memiliki reliabilitas yang baik karena memiliki nilai dibawah 0.7. Buruknya reliabilitas pada faktor sosio-emosional dan kognitif terjadi karena jumlah item yang kurang. Menurut Hair dkk (2014) reliabilitas cronbach alpha dilakukan dengan cara meninjau konsistensi internal antar item dalam skala. Dalam hal ini faktor sosio-emosional dan kognitif yang jumlah itemnya sedikit menimbulkan opsi pembanding antar item dalam skala menjadi kurang dan sulit. Item yang dieliminasi pada setelah Ekstraksi dan rotasi faktor yang dilakukan berdasarkan kriteria eigenvalues adalah item 1 karena tidak memiliki factor loading yang memenuhi kriteria validitas, yaitu diatas 0.4 (Field, 2018). Hasil tersebut dapat terjadi karena item 1 dipersepsikan oleh responden sebagai pertanyaan yang mengonfirmasi aspek pemanfaatan teknologi digital, bukan sebagai aspek kognitif yang melibatkan proses berpikir secara kompleks (Kalyuga, Renkl, \& Paas, 2010). Sedangkan item 5 yang dirancang untuk mengukur dimensi teknik dalam skala digital literacy memiliki factor loading yang tinggi pada faktor kognitif. Hal ini dapat terjadi karena kalimat "saya tahu cara menyelesaikan persoalan" pada item 5 dipersepsikan responden sebagai suatu konsep problem solving yang merupakan salah satu konsep dalam bidang kognitif (Kalyuga, Renkl, \& Paas, 2010).

Pada ekstraksi faktor berdasarkan kriteria fixed number reliabilitas yang dihasil cukup sama dengan penelitian sebelum yang dilakukan oleh Üstündağ dkk (2017), yaitu diatas 0,80. Meskipun demikian perbedaan ditemukan terkait jumlah item yang dieliminasi, dimana pada penelitian ini terdapat 3 item yang dieliminasi karena tidak memenuhi kriteria factor loading yang ditentukan. Secara spesifik item terebut adalah item 1,3, dan 4. Hal ini dapat terjadi karena 3 item tersebut dipersepsikan oleh responden sebagai suatu pertanyaan yang mengonfirmasi pemanfaatan teknologi secara pragmatis. Pragmatis sendiri berfokus pada luaran dari sesuatu yang dilakukan atau dipikirkan (Korte \& Mercurio, 2017). Berbeda dengan 7 item lainnya yang dipersepsikan oleh responden sebagai pertanyaan terkait suatu keterampilan yang digunakan dalam penggunaan teknologi digital (Üstündağ, Güneş, \& Bahçivan, 2017).

Pada Ekstraksi dan rotasi faktor yang dilakukan berdasarkan kriteria eigenvalues, hasil faktor yang dihasilkan sesuai dengan dimensi operasionalisasi konsep digital literacy Ng (2012), yaitu faktor kogntif, sosio-emosional, dan teknik. Hal ini menunjukan bahwa faktor kognitif, sosio-emosional, dan teknik dapat mempresentasi konsep digital literacy Ng (2012) pada individu dewasa awal. Keberadaan faktor ini dapat dimanfaatkan dalam mengurangi digital divide. Menurut Deursen \& Dijk (2010) digital divide merujuk pada perbedaan/gap dalam mengakses teknologi digital. Deursen \& Dijk (2010) menjelaskan bahwa digital divide menjadi faktor yang mempengaruhi digital literacy. pendidikan menjadi faktor kontributor penting pada literasi digital/kemampuan internet individu dan fenomena digital divide. Pemerintah dapat menggunakan faktor-faktor telah diuraikan diatas sebagai komponen materi psikoedukasi terkait literasi digital dalam rangka mengurangi digital divide.

Analisis alat ukur yang dilakukan pada penelitian ini menunjukan hasil yang cukup valid, sehingga dapat digunakan dalam operasionalisasi pengukuran konsep digital literacy pada individu dewasa awal. keberadaan alat ukur digital literacy ini juga dapat memberikan implikasi dalam mengeksplorasi permasalahan terkait fenomena perilaku penggunaan teknologi digital pada individu dewasa awal 
(Rodríguez, Igartua, \& González-Vázquez, 2016). Skala digital literacy menjadi sarana asesmen prevensi dampak negatif yang muncul dari penggunaan teknologi pada individu dewasa awal (Rodríguez, Igartua, \& González-Vázquez, 2016). Selain prevensi dampak negatif, skala digital literacy juga dapat dimanfaatkan sebagai asesmen dalam program-program yang terkait dengan kebutuhan masa perkembangan individu dewasa awal, seperti berwarganegara, bekerja, dan membangun hubungan sosial. Pada bidang berwarga negara, konsep digital citizenship menjelaskan bahwa dalam menjalin hubungan komunikasi di lingkungan digital individu perlu mempunyai kemampuan untuk memperluas jaringan informasi agar dapat terhubung dengan individu lain dan terlibat dalam aktivitas berwarganegara, dikarenakan pada lingkungan digital terdapat banyak pemahaman terkait definisi berwarganegara (Choi, Glassman, \& Cristol, 2017). Dalam hal ini digital literacy berfungsi untuk mengurangi perbedaan pengetahuan informasi dalam lingkungan digital dan dapat melakukan aktivitas warga negara secara tepat dan optimal (Choi, Dkk., 2017; Hargittai, 2008). Tekait dengan bidang pekerjaan, teknologi digital telah menjadi aspek yang penting dan digunakan dalam mengefektifkan pekerjaan pada lingkungan kerja (Zhang, et al., 2013). Kebaradaan digital literacy bagi individu dewasa awal menjadi sebuah kemampuan yang esensial pada berbagai bidang pekerjaan, sehingga kompetensi dalam penggunaan teknologi digital menjadi sesuatu yang wajib dimiliki dalam masyarakat (Osterman, 2012). Oleh karena itu alat ukur digital literacy pada penelititan dapat dimanfaatkan sebagai asesmen pengukuran literasi digital individu dewasa awal terkait kebutuhan yang dibutuhkan.

Hambatan penelitian dalam penelitian ini adalah terkait jumlah subjek penelitian yang berpartisipasi pada penelitian ini. Menurut Field (2018) Analisis EFA akan semakin baik jika dilakukan dengan jumlah subjek yang banyak. Pada penelitian ini sendiri jumlah minimal sampel yang digunakan menggunakan rule of thumb Jackson (2003) yang paling kecil, yaitu menggunakan rumus N:q dengan ratio 5:1 (Kline, 2011). Pada penelitian selanjutnya diharapkan pada menggunakan sampel yang lebih besar sehingga memiliki hasil yang lebih baik dan representatif.

\section{S I M P U L A N}

Hasil penelitian ini menunjukan bahwa alat ukur skala digital literacy milik Ng (2012) pada penelitian ini memiliki validasi yang baik pada populasi individu dewasa awal. Hasil reliabilitas pada bebeberapa faktor juga menunjukan bahwa memiliki nilai yang cukup baik. Eliminasi item dilakukan pada penelitian ini karena terdapat beberapa item yang tidak memiliki factor loading yang sesuai kriteria. Meskipun belum sempurna dan terdapat sejumlah catatan yang perlu diperbaiki pada penelitian berikutnya, namun penelitian ini telah memberikan hasil uji validitas reliabilitas yang cukup baik tentang skala digital literacy yang diujikan pada individu dewasa awal. Oleh karena itu skala digital literacy ini dapat digunakan sebagai instrument asesmen yang ditujukan untuk individu dewasa awal oleh pihak-pihak terkait pada bidang teknologi digital.

\section{U C A P A N T ER I MAKASIH}

Penulis mengucapkan terima kasih kepada partisipan serta pihak-pihak yang mendukung penulis sehingga penelitian ini dapat dilaksanakan dengan baik. 


\section{DEKLARASI POTENSI TERJADINYAKONFLIK KEPENTINGAN}

Fithra Auliawan dan Rahkman Ardi tidak bekerja, menjadi konsultan, memiliki saham, atau menerima dana dari perusahaan atau organisasi manapun yang mungkin akan mengambil untung dari diterbitkannya naskah ini.

\section{PUS TAKA ACUAN}

Aagaard, J. (2014). Media multitasking, attention, and distraction: a critical discussion. Phenomology and The Cognitive Sciences , 885-896.

Alfarizi, M. K. (2019, march 4). Tempo. Retrieved from Tempo.co: https://tekno.tempo.co/read/1181645/survei-kepemilikan-smartphone-indonesia-peringkatke-24/full\&view $=$ ok

Almanasreh, E., Moles, R., \& Chen, T. F. (2006). Evaluation of methods used for estimating content validity. Research in Social and Administrative Pharmacy, 214-221.

Ardi, R., \& Maison, D. (2014). How do Polish and Indonesian disclose in Facebook? Differences in online self-disclosure, need for popularity, need to belong and self-esteem . Journal of Information, Communication and Ethics in Society, 195-218.

Astrid, E., \& Ardi, R. (2018). Pengaruh Narsisme dan Kebutuhan Rekognisi Terhadap Perilaku Pencarian "like" pada Pengguna Instagram. Surabaya: Fakultas Psikologi Universitas Airlangga.

Barak, A. (2008). Psychological Aspects of Cyberspace. New York: Cambrige Univerisity Press.

Bawden, D. (2001). Information and digital literacies; a review of concepts. Journal of Documentation, 218-259.

Bawden, D. (2008). Origins and Concepts of Diital Lieracy. In C. Lankshear, \& M. Knobel, Digital Literacies: Concepts, Policies and Practices (pp. 17-32). New York: Peter Lang.

Brasel, S. A., \& Gips, J. (2011). Media Multitasking Behavior: Concurrent Television and Computer Usage. CyberPsychology, Behavior, and Social Networking , 527-534.

Choi, M., Glassman, M., \& Cristol, D. (2017). What It Means to Be A Citizen Internet age: Development of A Reliable and Valid Digital Citizenship Scale. Journal Computer \& Education, 100-112.

Circella, G., Mokhtarian, P. L., \& Poff, L. K. (2012). A Conceptual Typology of Multitasking Behavior and Polychronicity Preferences. Electronic International Journal of Time Use Research , 59-107.

Cohen, L., \& Manion, L. (1989). Research Method In Education. New York: Routledge.

Coolican, H. (2014). Research Methods and Statistics in Psychology. New York: Psychology Press.

Deursen, A. V., \& Dijk, J. V. (2010). Internet skills and the. new media \& society, 893-911. 
Eshet, Y. (2004). Digital Literacy: A Conceptual Framework for Survival Skills in the Digital Era. Journal of Educational Multipedia and Hypermedia, 93-106.

Eshet, Y. (2009). Real-time thinking in the digital era. Encyclopedia of Information Science and Technology, Second Edition, 3219-3223.

Eshet, Y., \& Chajut, E. (2009). Changes Over Time in Digital Literacy. CyberPsychology \& Behavior, 1-3.

Field, A. (2018). Discovering Statistics Using IBM SPSS Statistics. London: Sage Publications.

Gati, A., Tenyi, T., Tury, F., \& Wildmann, M. (2002). Anorexia nervosa following sexual harassment on the internet: A case report. International Journal of Eating Disorder, 474-477.

Gilster, P. (1997). Digital Literacy. New York: Willey.

Guo, R. X., Dopson, T., \& Petrina, S. (2008). Digital Natives, Digital Immigrants: An Analysis of Age and ICT Competency In Teacher Education. Journal Educational Computing Research, 235-254.

Haber, D. (2006). Life Review: implementation, Theory, Research, and Therapy. Journal Aging and Human Development, 153-171.

Hadi, A. (2018). Bridging Indonesia's Digital Divide: Rural-Urban Linkages? Jurnal Ilmu Sosial dan Ilmu Politik, 17-33.

Hair, J. F., Black, W. C., Babin, B. J., \& Anderson, R. E. (2014). Multivariate Data Analysis Seventh Edition. Essex: Pearson Education Limited.

Hardaningtyas, D., \& Suryanto. (2004). Pengaruh Tingkat Kecerdasan Emosi dan Sikap pada Budaya Organisasi Terhadap Organizational Citizenship Behavior (OCB) Pegawai PT (Persero) Pelabuhan Indonesia III. Surabaya: Perpustakaan Universitas Airlangga .

Hargittai, E., \& Hinnant, A. (2008). Digital Inequality Differences in Young Adults'Use of the Internet. Journal Communication Research, 602-621.

Haryanto, A. T. (2019, may 16). Detik. Retrieved from Detik.com: https://inet.detik.com/telecommunication/d-4551389/pengguna-internet-indonesiadidominasi-milenial

Hoof, D. L., \& Mitchell, S. N. (2009). Cyberbullying: causes, effects, and remedies . Journal of Educational Administration , 652-665.

Hutteman, R., Hennecke, M., Orth, U., Reitz, A. K., \& Specht, J. (2014). Developmental Tasks as a Framework to Study Personality Development in. European Journal of Personality, 267-278.

Iskandar. (2017, February 2). Liputan6. Retrieved from Liputan6.com: https://www.liputan6.com/tekno/read/2844292/sdm-tik-kurang-kompeten-ri-belummampu-saingi-negara-maju 
Jennings, M. K. (2007). Political Socialization. In R. J. Dalton, \& H. D. Klingemann, The Oxford Handbook of Political Behavior (pp. 29-44). New York: OxfordUniversity Press.

Joinson, A. N. (2001). Self-disclosure in computer-mediated communication: The role of self-awareness and visual anonymity. European Journal of Social Psychology , 177-192 .

Kahne, J., Lee, N.-j., \& Feezell, J. T. (2013). The Civic and Political Significance of Online Participatory Cultures among Youth Transitioning to Adulthood. Journal of Information Technology \& Politics, 1-20.

Kalyuga, S., Renkl, A., \& Paas, F. (2010). Facilitating Flexible Problem Solving: A Cognitive Load Perspective. Education Psychology Revision, 175-186.

Kline, R. B. (2011). Principles and Practice of Structural Equation Modeling. New York: The Guilford Press.

Koc, M., \& Barut, E. (2016). Development and Validation of New Media Literacy Scale (NMLS) for University Student. Computer in Human Behavior, 834-843.

Koltay, T. (2011). The media and the literacies: media literacy, information literacy, digital literacy. journal Media, Culture \& Society, 211-221.

Korte, R., \& Mercurio, A. A. (2017). Pragmatism and Human Resource Development: Practical Foundations for Research, Theory, and Practice. Human Resource Development Review, 60-84.

Kroger, J. (2015). Identity Development Through Adulthood: The Move Toward "wholeness". In K. C. McLean, \& M. Syed, The Oxford Handbook of Identity Development (pp. 65-81). New York: Oxford University Press .

Kumparan. (2018, 04 27). Kumparan. Retrieved from Kumparan.com: https://kumparan.com/banjarhits/ugm-literasi-digital-di-masyarakat-indonesia-masihburuk/full

Kurnia, N., \& Astuti, S. I. (2017). Peta Gerakan Literasi Digital di Indonesia: Studi Tentang Pelaku, Ragam Kegiatan, Kelompok Sasaran dan Mitra . Jurnal Informasi, 149-165.

Lechner, C. M., Sortheix, F., Gollner, R., \& Katarina. (2017). The development of work values during the transition to adulthood: A two-country study. Journal of Vocational Behavoir, 52-65.

Ng, W. (2012). Can we teach digital natives digital literacy? Computers \& Education, 1065-1078.

Noh, Y. (2017). A study on the effect of digital literacy on information use behavior. Journal of Librarianship and Informational Science, 26-56.

Osterman, M. D. (2012). Digital Literacy: Definition, Theoretical Framework, and Competencies . Proceedings of the 11th Annual College of Education \& GSN Research Conference (pp. 135-141). Mami: Florida International University. 
Park, Y. J. (2011). Digital Literacy and Privacy Behavior Online. Communication Research , 215-236.

Peterson, C. H., Powell, K. G., \& Peterson, N. A. (2017). Cognitive Interviewing for Item Development: Validity Evidence based on Content and Response Processes. Measurement and Evaluation in Counseling and Development, 217-223.

Polit, D. F., \& Beck, C. T. (2006). The Content Validity Index: Are you Sure You Know What's Being Reported? Critique and Recomendations. Research in Nursing \& Health, 489-497.

Prasetyo, B., \& Trisyanti, U. (2018). REVOLUSI INDUSTRI 4.0 DAN TANTANGAN PERUBAHAN SOSIAL. IPTEK, 22-27.

Prensky, M. (2001). Digital Natives, Digital Immigrants. NCB University Press, 1-6.

Prior, D. D., Mazanov, J., Meacheam, D., Heaslip, G., \& Hanson, J. (2016). Attitude, digital literacy and self efficacy: Flow-on effects for online. Internet and Higher Education, 91-97.

Puspitasari, L., \& Ishii, K. (2016). Digital divides and mobile Internet in Indonesia: Impact of smartphones. Telematics and Informatics, 472-483.

Rauch, S., Tebb, S. S., Lee, S. E., Berg-Weger, M., \& Rubio, D. M. (2003). Objectifying content validity: Conducting a content validity study in social work research. Social Work Research, 94-104.

Rice, E. S., Haynes, E., Royce, P., \& Thompson, S. C. (2016). Social media and digital technology use among Indigenous young people in Australia: a literature review. International Journal for Equity in Health , 1-16.

Rodríguez, I., Igartua, J.-j., \& González-Vázquez, A. (2016). Development and Validation of a Digital Literacy Scale for Teenagers. Proceedings of the Fourth International Conference on Technological Ecosystems for Enhancing Multiculturality, 1067-1073.

Schultz, D. P. (2016). Teori Kepribadian. Jakarta: EGC.

Sperber, A. D. (2004). Translation and Validation of Study Instruments for Cross-Cultural Research. Gastroentology, 124-128.

Sprinthall, R. C., Schmutte, G. T., \& Sirois, L. (1991). Understanding Educational Research. New Jersey: Prentice-Hall Inc.

Suler, J. (2004). The Online Disinhibition Effect. Cyber Psychology \& Behavior, 321-326.

Svetina, M. (2014). Resilience in the context of Erikson's theory of human development. Current Psychology, 393-404.

Tapscott, D. (2009). Grow Up Digital. New York: McGraw-HIll Companies. 
UNESCO. (2019). Recommendations on Assessment Tools for Monitoring Digital Literacy within UNESCO'S Digital Literacy Global Framework. quebec: UNESCO Institute for Statistics.

Üstündağ, M. T., Güneş, E., \& Bahçivan, E. (2017). Turkish Adaptation of Digital Literacy Scale and Investigating Pre-service Science Teachers' Digital Literacy. Journal of Education and Future , 1929.

Van De Vijver, F. J. (2016). Test Adaptations. In F. T. Leong, D. Bartram, F. M. Cheung, K. F. Geisinger, \& D. Iliescu, The ITC International Handbook Of testing and Assessment (pp. 364-376). New york: Oxford University Press.

Willis, G. B. (2015). Analysis Of The Cognitive Interview In Questionnaire Design. New York: Oxford University Press .

Wu, C.-Y., Lee, M.-B., Shih-Cheng, L., \& Chang, L.-R. (2015). Risk Factors of Internet Addiction among Internet Users:An Online Questionnaire Survey. PLoS ONE, 1-10.

Ybarra, M. L., Mitchell, K. J., Wolak, J., \& Finkelhor, D. (2006). Examining Characteristics and Associated Distress Related to Internet Harassment: Findings From the Second Youth Internet Safety Survey. Pediatrics, 1169-1177.

Zhang, Y., Mao, M., Rau, P.-L. P., Choe, P., Bela, L., \& Wang, F. (2013). Exploring Factor Influencing Multitasking Interaction with Multiple Smart Devices. Computer in Human Behavior, 2579-2588. 